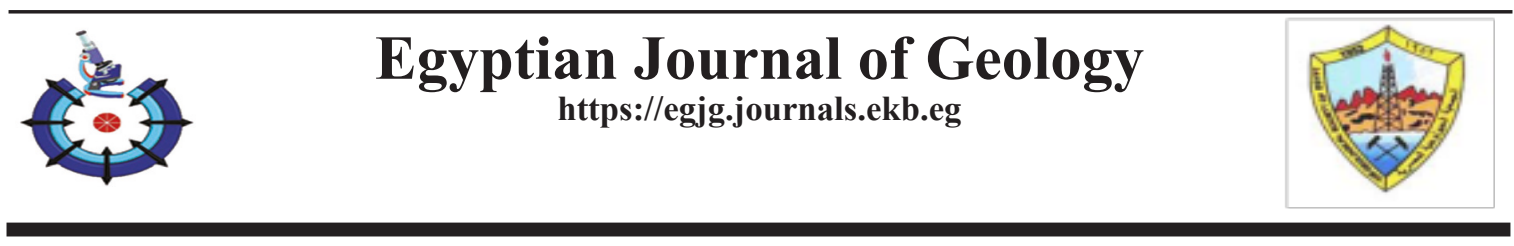

\title{
Strata-bound Colonnade Fractures in Argillaceous Sediments of Qasr EI Sagha Delta, Fayum-Egypt.
}

\author{
Mohamed S. Hammed \\ Geology Department, Faculty of Science, Cairo University, Egypt
}

\begin{abstract}
$\mathbf{T}$
HIS work reports spectacular and unique strata-bound columnar fractures in Late Eocene argillaceous sediments of Qasr El Sagha Delta, Fayum-Egypt. Polygonal fractures are widely distinguished as syn-sedimentary structures attributed to dewatering and simultaneous shrinkage of fine-grained sediments. Exposures permitted visualization of the progressive fracture growth along ca 2 meters high colonnade pillars. The increasing diameter and fracture apertures correlate well with the confined clay thickness. Tetragonal fractures are dominant in ca $3-10 \mathrm{~cm}$ clay layers, while the hexagonal pattern is dominant in $\mathrm{ca}>30 \mathrm{~cm}$ thick clay beds. Fracture polygons of high frequency, order, and geometrical uniformity are better developed in montmorillonite-rich clays. Fractures have curved and en-passant patterns of ductile clay fracturing during the colloidal phase. Fracturing was developed in substrata conditions under few meters of burial sediments. Fracture apertures either increase or decrease toward the top and bottom layers of better permeability. A decrease of fracture apertures toward the top and bottom sand and silt indicates fracture initiation inside the colloid and limited fluid flows during fracturing. Fracture fills are of two natures: sand injection and deposition of unconsolidated laminated sands with delicate gastropod shells. Occasionally, clay layers form domes and sags with fracture rosettes and filamentous complex networks injected by sand. Mild and episodic seismicity was the main cause of dewatering (water escaping) and fracturing. This study might help during the evaluation of the subsurface non-conventional reservoirs in the Nile Delta, which underwent the same geological conditions.
\end{abstract}

Keywords: Colonnade fractures, colloidal phase, dewatering, syneresis, seismicity, Qasr El Sagha Formation.

\section{Introduction}

The present work documents a unique geologic occurrence for strata-bound colonnade (columnar) fractures in argillaceous deposits exposed on the eastern bank of Qarun Lake in Fayum, Egypt (Fig. 1). Restriction of the cracks to fine-grained beds embedded in coarse-grained clastics constrains the interpretation of these cracks. Numerous exposures of Late Eocene Qasr El Saga Formation for bentonite quarrying at Kom Oshem offer an opportunity to investigate clay-bound columnar fractures in both cross-sectional and plan views. Detailed field description of fracture morphology and geometry, and grain size, clay/sand ratio, and identification of clay mineralogy of fractures bearing stratigraphic intervals have been carried out by systematic microscopic investigation and $\mathrm{X}$-ray diffraction analysis.

The first account on strata-bound polygonal columnar fractures was in volcanic rocks and attributed to shrinkage while lava cooling (Mallet, 1875). Columnar fracturing is thought to occur primarily in lavas, welded pyroclastic flows, and thermal and pyrometamorphosed sandstone (Summer and Ayalon, 1995; and Grapes, 2006). Fractures are widely recognized in argillaceous sediments. Loss of pore water during the domination of variable processes (e.g., drying, heating, burial \& seismicity) is simultaneously 
associated with grain compaction and volume loss causing shrinkage fracturing. Subaerial desiccation is assumed the common drying process (Allen, 1987; Kidder, 1990; and Wilde, 1990). Polygonal faults and fractures confined to thick clays and chalk were assumed to be developed during basin compaction (Cartwright and Dewhurst, 1998; and Gay, et al., 2004). Surface occurrence of polygonal faults within the late Cretaceous fine chalk in Farafra environs was proposed by Tewksbury, et al. (2014). The rift-related volcanic occurrences in Sinai and the western Desert of Egypt exhibit extensive and predominant columnar (colonnade) fractures of thermal cooling origin (Shalaly, et al., 2013, Bosworth, et al., 2015, Khalaf, and Hammed, 2016). Syneresis cracking explains the development of some mud cracks in flocculated clay gel (colloid) during the expulsion of excess water and simultaneous shrinkage of clay (White, 1961; Scherer, 1986; Brinker and Scherer, 1990; and Hughes and Hesselbo,1997). Shrinkage cracks occur at the sediment interface, either with water or air/ or during sedimentary burial in substratal conditions. Pratt (1998) ascribed shrinkage cracks to seismicity in subaqueous conditions. The shrinkage processes produce fractures with different morphological aspects (Plummer and Gostin, 1981), so, the associated sedimentary features and geological data remain essential during fracture interpretation. The present work reports the morphological aspects of stratabound colonnade fractures and their growth and provides criteria of intrastratal dewatering, shrinkage, and fracture formation mechanism.

\section{Geologic setting}

A succession of clay and sand was deposited during the progradation of a delta system in the Late Eocene (Salem, 1976; and Abdel-Fattah, et al., 2010) which is known as Qasr El Sagha (Palace of gold) Delta (Fig. $1 \mathrm{~A} \& \mathrm{~B})$. These sediments host fossil mammals and other vertebrates (Andrews, 1901; and Holroyd, et al., 1996) that rank the area as an international heritage site. The name of Qasr El Sagha Formation was introduced by Beadnell (1905) to describe the Carolia plucnoides rich stratigraphic interval of cyclic sand, silt, and clay at Qasr El Sagha area, Fayum, Egypt. The formation was subdivided into two members: the lower Temple Member and the upper Dir Abu Lifa Member (Fig. 1C, Said, 1962). The exposed stratigraphic units in the study area represent the middle part of the Temple Member of Qasr El Sagha Formation (Fig.1C). The NWdipping prograded delta clinoforms were traced in the northern part of the area (Fig.1D\&E). The different grain size proportions are based on the location in the roughly northward propagating delta and distance from the mouth charge of the clastics. The low relief topography of the immediate northern bank of Qarun Lake is represented by table-land morphology (Fig. 1D). This area has been subjected during the last 15 years to extensive quarrying of claystone (Figs. 1D and 2A). Periodical visits to these quarries revealed the first record of unique colonnade fractures restricted to clayrich beds (Fig. 2A unit 3). Quarrying stopped in the last couple of years and local farmers started manual extraction of mudstone for land reclamation. The newly excavated faces exhibited the same fracture systems. Present field investigations recognized numerous synsedimentary deformations associated with the deposition of the Qasr El Sagha Delta system (Fig. 1E). The deformation is confined to certain stratigraphic intervals and associated with mobility of argillaceous beds and variation in sedimentary thickness. Synsedimentary faults range in length and displacement from a few $\mathrm{cm}$ to hundreds of $\mathrm{m}$ (Fig. 2C\&D).

In the study area, the stratigraphic section of the Temple Member is divided into three intervals with various clay-bound fractures (Fig. 2A\&B). The lower interval (interval 1, Fig. 2B) is mainly composed of 3-5 $\mathrm{m}$ of medium to coarse-grained unconsolidated sands deposited in submarine channels. In this interval, the prevalence of scouring surfaces, convolute bedding, and recumbent crossbeddings indicate a high energy environment and slumping during deposition (Fig. 3). The uppermost part of the lower interval comprises some thin fractured argillaceous beds of 10 $30 \mathrm{~cm}$ thickness (Fig. 3).

The middle interval (interval 2, Fig. 2B) is 2 to $4 \mathrm{~m}$ thick and consists of intercalated fine argillaceous cross-bedded sand, silt, and claystone layers. The stratigraphic section is graded upward into the upper interval (interval 3 , Fig. 2B) of $1-5 \mathrm{~m}$ thick claystone with characteristic polygonal fractures fashioned in colonnades. The clays contain fine quartz grains of different ratios $(10-30 \%$ of the total volume, Fig. 4A \& B). Laterally, the clay

Egypt. J. Geo. Vol. 65, (2021) 
changes to silty claystone and argillaceous sandstone (Fig. 4C). Mineralogically, the clay is a mixture of montmorillonite and kaolinite in different proportions between $1: 1,2: 1$, and $1: 2$ with $2-4 \%$ illite percent, as indicated by the XRD analysis (Fig. 4D-F). However, in some samples, kaolinite is the only constituting clay mineral. The colonnade-rich interval is overlain by well-bedded sandstone that shows weak fracturing and granular flow. The latter sandstone is scoured in places by submarine channels (Fig. 2B). The uppermost part of the stratigraphic section consists of roughly northward prograded delta-clinoforms of mainly sand composition (Fig.1E).

Fracture characteristics: morphology and geometric patterns

In the lower stratigraphic interval, the $10-30 \mathrm{~cm}$ - thick argillaceous beds show layer-confined polygonal fractures, roughly orthogonal to bedding (Fig. 3A-E). These fractures form a tetragonal pattern with an irregular sinuous shape. The width of fracture apertures increases decreases or is the same. Several open fracture apertures change from $2-5 \mathrm{~mm}$ width within the clay to $1-2 \mathrm{~mm}$ toward the contact with the intercalated sand and less than $1 \mathrm{~mm}$ in the intercalated, $2-5 \mathrm{~mm}$ - thick sand laminae (Fig. 3D). Fractures also have the same width in clay but are thin in sand intercalations (Fig. 3B \& C). In some cases, the width of fracture apertures is $2-5 \mathrm{~mm}$ near the contact with sand intercalations but tightens $(1 \mathrm{~mm})$ in clay (white box in Fig. 3B). Coarse sand layers were found to be free of fractures.

In the middle stratigraphic interval, the argillaceous sediments show fractures of 20$40 \mathrm{~cm}$ diameter and up to $1 \mathrm{~m}$ height (Fig. 5A). Many of the dissecting fractures within the clay and the intercalations of silt and sand show millimeters to few centimeters vertical displacements (Fig. 5A-D). In the vertical profile, the collinear and closely spaced tips of fractures are linked within the embedded argillaceous fine sand to form one continuous fracture. In other cases, the en-passant fractures show jogs in between the stepped fracture tips (Fig. 5B \& C). Although most of the fractures are roughly vertical, the oppositely inclined fracture segments exhibit an arcuate fracture pattern (Fig. 5D). The upper arc dips in order of $55-70^{\circ}$, while the lower part of arcs is steeper with a $70-75^{\circ}$ dip angle in the counter direction. Linkage and en-passant fractures are mainly found in the silty and fine sandy facies, either with primary sedimentary fabrics or without (Fig. 5B\&C). These fractures are either invaded or not by the surrounding sand.

The upper clay-rich interval is distinguished by characteristic well-developed pillars of colonnades (Fig. 5E). Their outlined fracture surfaces lack the features associated with extensional fracturing of solid rocks, such as shuttering, hackle, and plumose ornamentations. The colonnades' plan views are mainly of hexagonal and subordinate pentagonal and tetragonal forms (Fig. 5F \& G). Although colonnades reach up to $75 \mathrm{~cm}$ in diameter, some of them are vertically fractured into smaller colonnade pillars. Radial fractures were recognized in some colonnades (Fig. 5F). The vertical variations of fracture apertures along the pillar axes have resulted in crooked colonnades (Fig. 5E). The fracture apertures range from few millimeters up to $20 \mathrm{~cm}$ and have a good positive correlation with the host clay thicknesses (Fig. 6).

The frequency and geometrical uniformity of the fractures show a relationship with changes in clay composition and lateral facies variations. Extensive fractures are concentrated in montmorillonite-rich clay where the pillars span the entire thickness of the claystone layer (Fig. 5E). The kaolinite-rich clays with subordinate illite show fewer fractures, whereas sites of composite montmorillonite-rich and kaolinite-rich exhibit fracture layering (Fig. 7A $\&$ E). Less fracture density and chaotic fracture arrangement were observed with the increasing of silt and fine sand detrital (Fig. 7B-F).

The colonnade pillars change from straight to curved-defined prisms in S and Z- shapes by a $10-22^{\circ}$ deviation angle from the vertical axis (Fig. 8A\&B). Further deviations of colonnades are associated with their failure along shears parallel to the sedimentary laminations (Fig. 8B). The clay of delta-clinoforms bound inclined colonnades against the direction of the delta-progradation and oblique to the foresets and topsets (Fig. 8C). The horizontality and non-disturbance of the topsets refer to passive contact. 


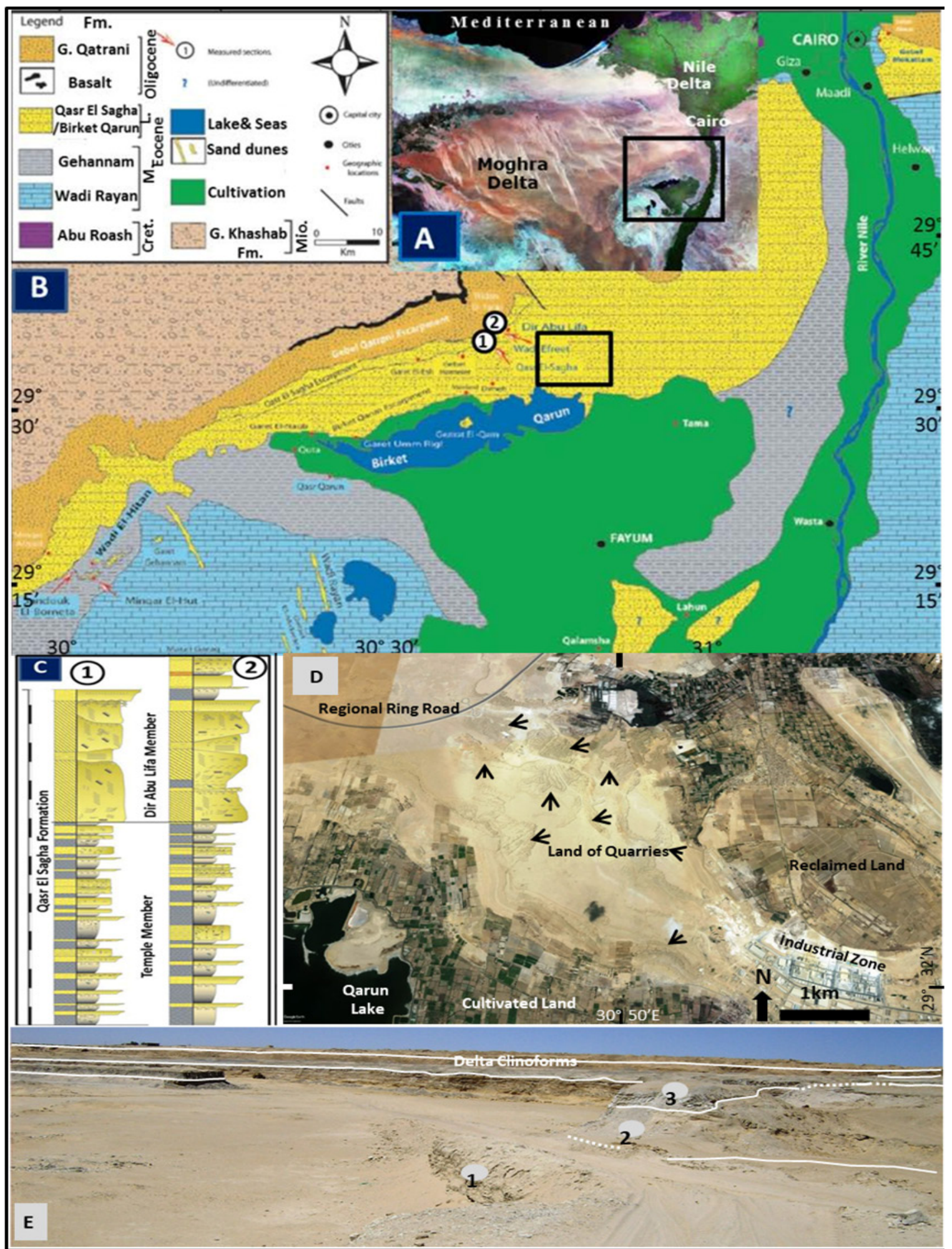

Fig. 1. A) Landsat image of Northern Egypt with the location of Fayum depression. (B) A simple geological map of the Fayum depression (reproduced by Abdel-Fattah, et al., 2010 based on works of Beadnell, 1905; Said, 1962; Gingerich, 1992; and Kusky, et al., 2001) shows the location of the study area as the black-bordered box. (C) the two measured stratigraphic sections by Abdel-Fattah, et al. (2010) at locations "1\&2" which are shown in (B). (D) Google image shows the land use and quarry excavations in the study area. (E) Quarry faces with lines separate between different stratigraphic intervals, looking NW.

Egypt. J. Geo. Vol. 65, (2021) 


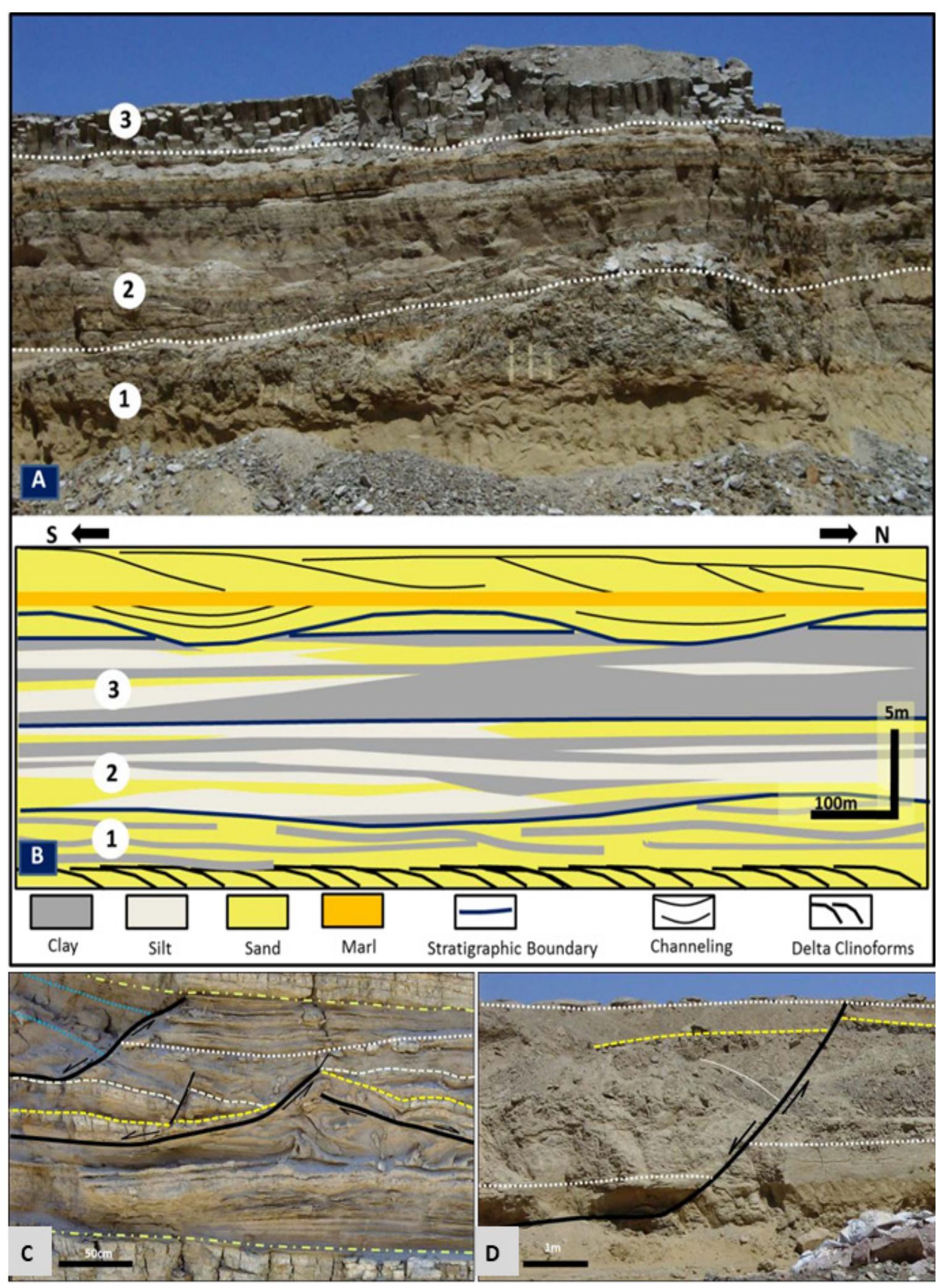

Fig. 2. A) Quarry faces show the three stratigraphic units bearing clays with different fracture patterns. (B) Sketch of the stratigraphic section of the clay-bound fractures. Nos. $1,2 \& 3$ refer to mentioned intervals in the text. C\&D) Syn-depositional normal faulting associated with the Qasr EI Sagha Delta buildup, east Qarun Lake area. Faults are restricted to certain stratigraphic intervals, Note convolute beds in $D$. 


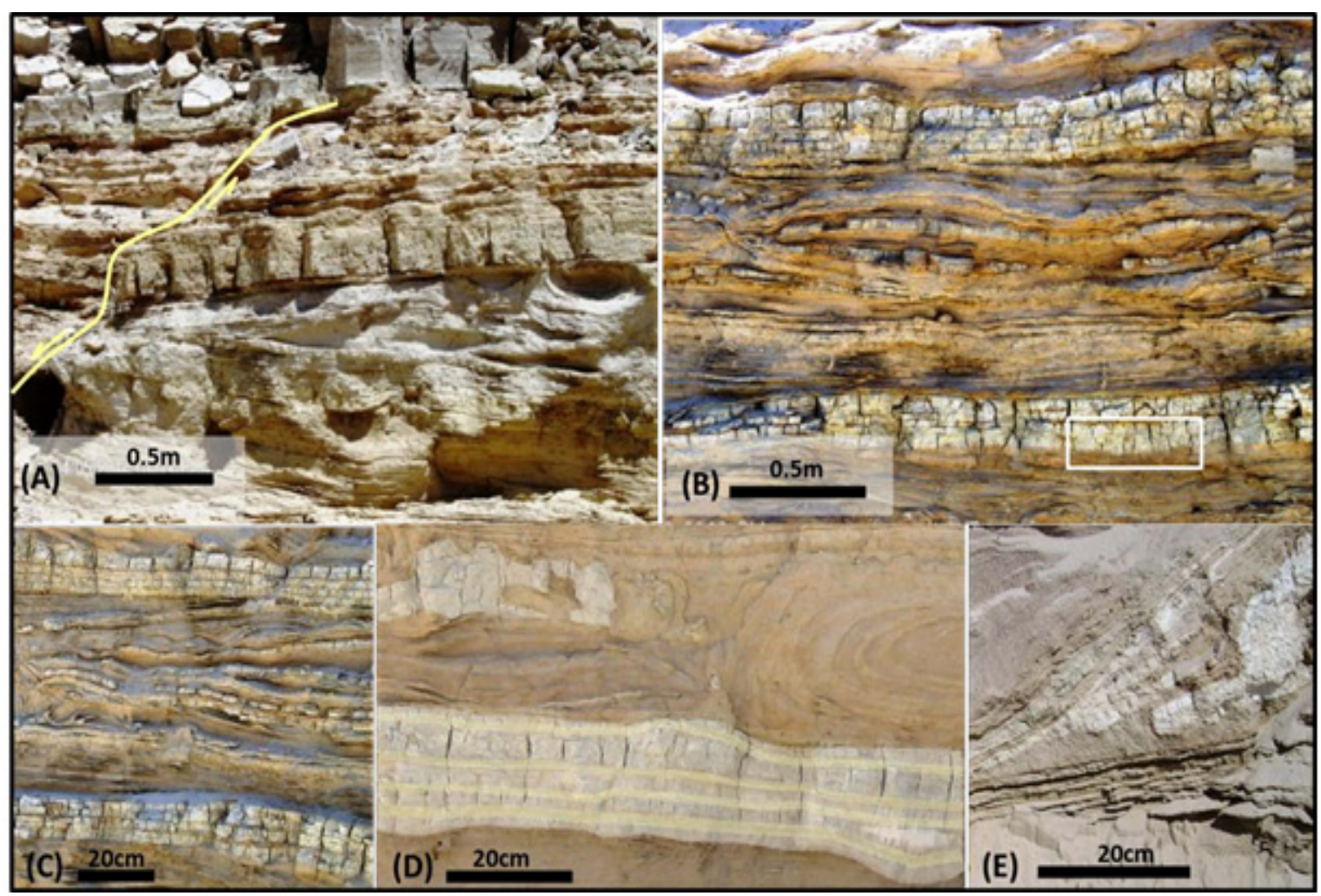

Fig. 3. (A) Thinly layered cross-bedded sand, siltstone, and fractured claystone. Note, pinching out, scouring, and faulting features. (B\&C) Sand with thin clay intercalations of $\mathrm{cm}$ - scale. The white box in (B) includes several open fracture apertures tighten inside the clay. (D) Clay strata-bound orthogonal fractures and recumbent and cross-bedded sandstone beds (upper left is the scoured tip of a layer extending left of photo). Open fractures' apertures tighten out of clay towards the confined sand. (E) Slumped clay and sandstone beds of active environment. Fractures are restricted to clay beds and mud-ball.

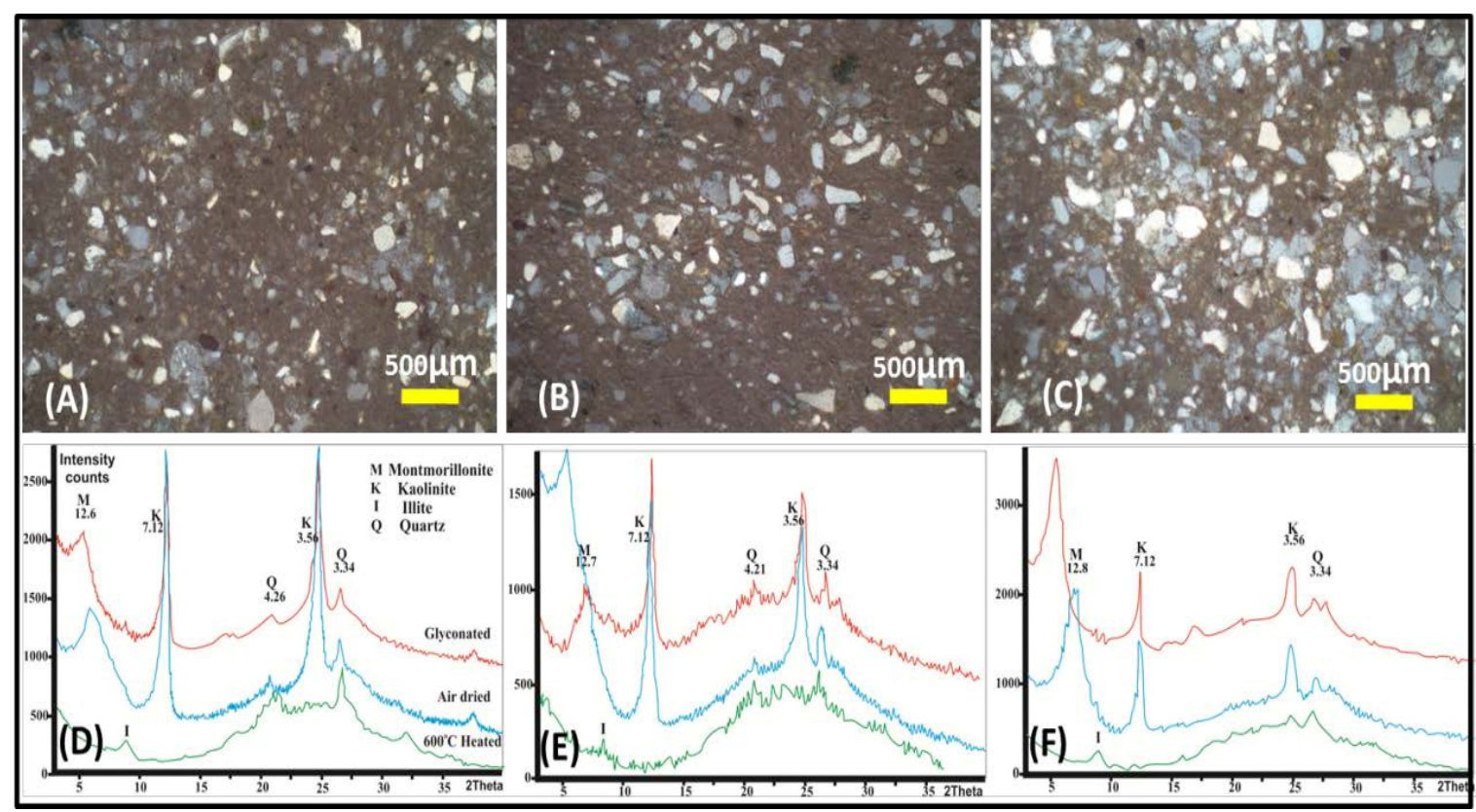

Fig. 4. (A, B \& C) Photomicrographs show the ratios of detrital quartz in clay and the grading of the sediments from clay-bearing sand to highly argillaceous sand. (D, E\&F) XRD results of clay samples, identify mixtures of montmorillonite(M), kaolinite (K), and little illite (I) with quartz (Q).

Egypt. J. Geo. Vol. 65, (2021) 


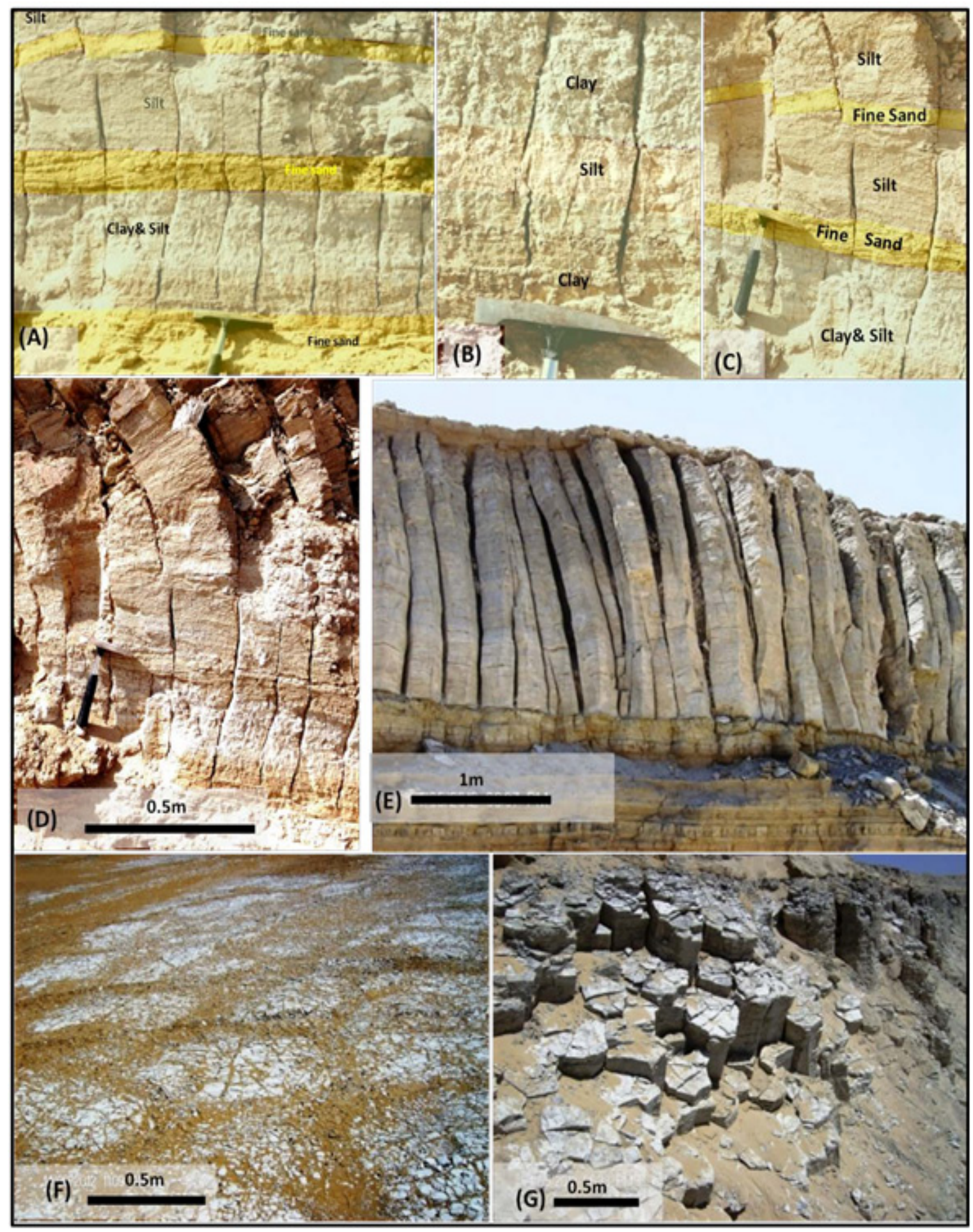

Fig. 5. (A) Intercalations of clay, silt, and argillaceous fine sand with linked and prolonged fractures across the different facies. (B) Linked fracture with small transferring segment near the claysilt boundary (right), and en-passant fractures. (C \& D) En-passant approaching fractures (middle of photo) and linkage of different dipping fractures in arcuate forms. (E) Curved and vertical colonnade pillars extending in the whole clay thickness interval with irregular open spaces in between. (F \& G) Top and oblique views showing colonnades with mainly hexagonal cross-sectional form. Additional fracturing causes the splitting of each column into small pieces. 


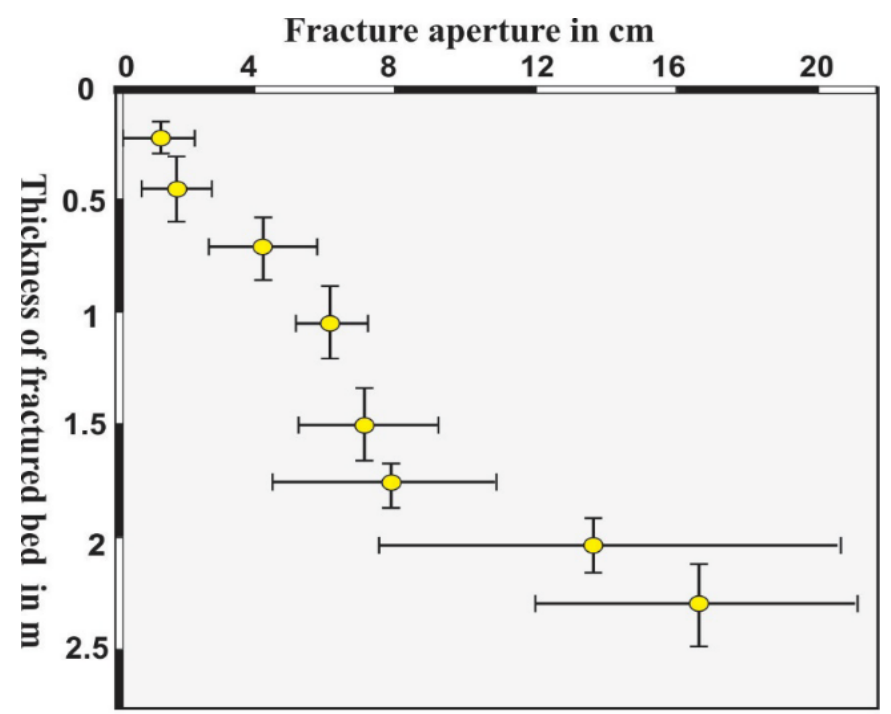

Fig. 6. Variation diagram showing the relation between the measured fracture aperture (in $\mathrm{cm}$ ) and thickness of the fractured bed (in $\mathrm{m}$ ).

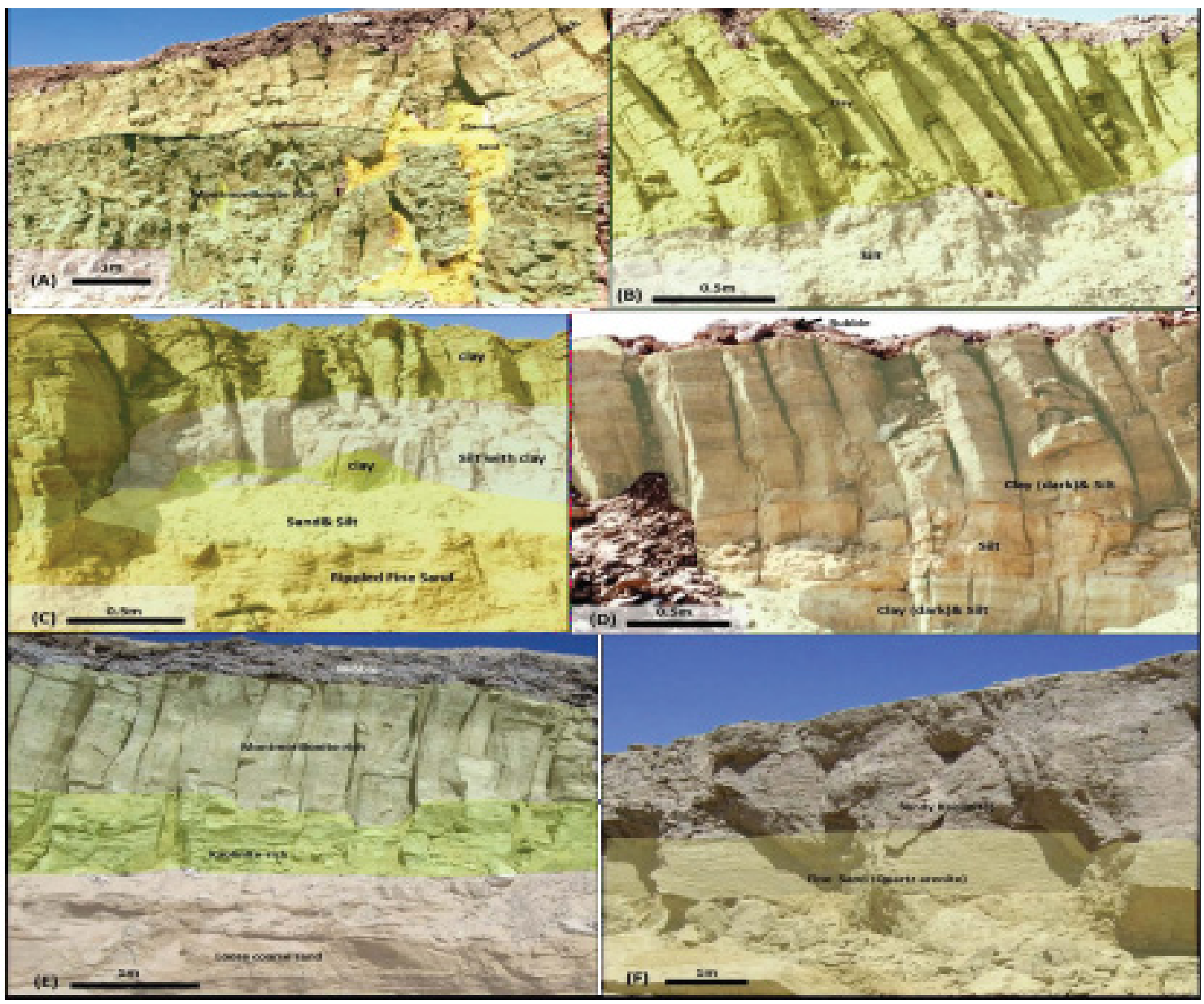

Fig. 7. (A) Layered fractures in composite clay section. The lower clay part is heavily fractured with sinuous planes that resemble ductile fracturing. The yellow patches refer to injected sand. The top layer is rubble. (B, C \& D) Well-developed fractures in clay interval, while silt and fine sand are gently fractured. (E) Decreasing fracture intensity and uniformity from the montmorillonite-rich to the kaolinite-rich interval. (F) Fracture walls lack uniformity in sandy kaolinite, and the lower argillaceous fine sand is chaotically fractured.

Egypt. J. Geo. Vol. 65, (2021) 

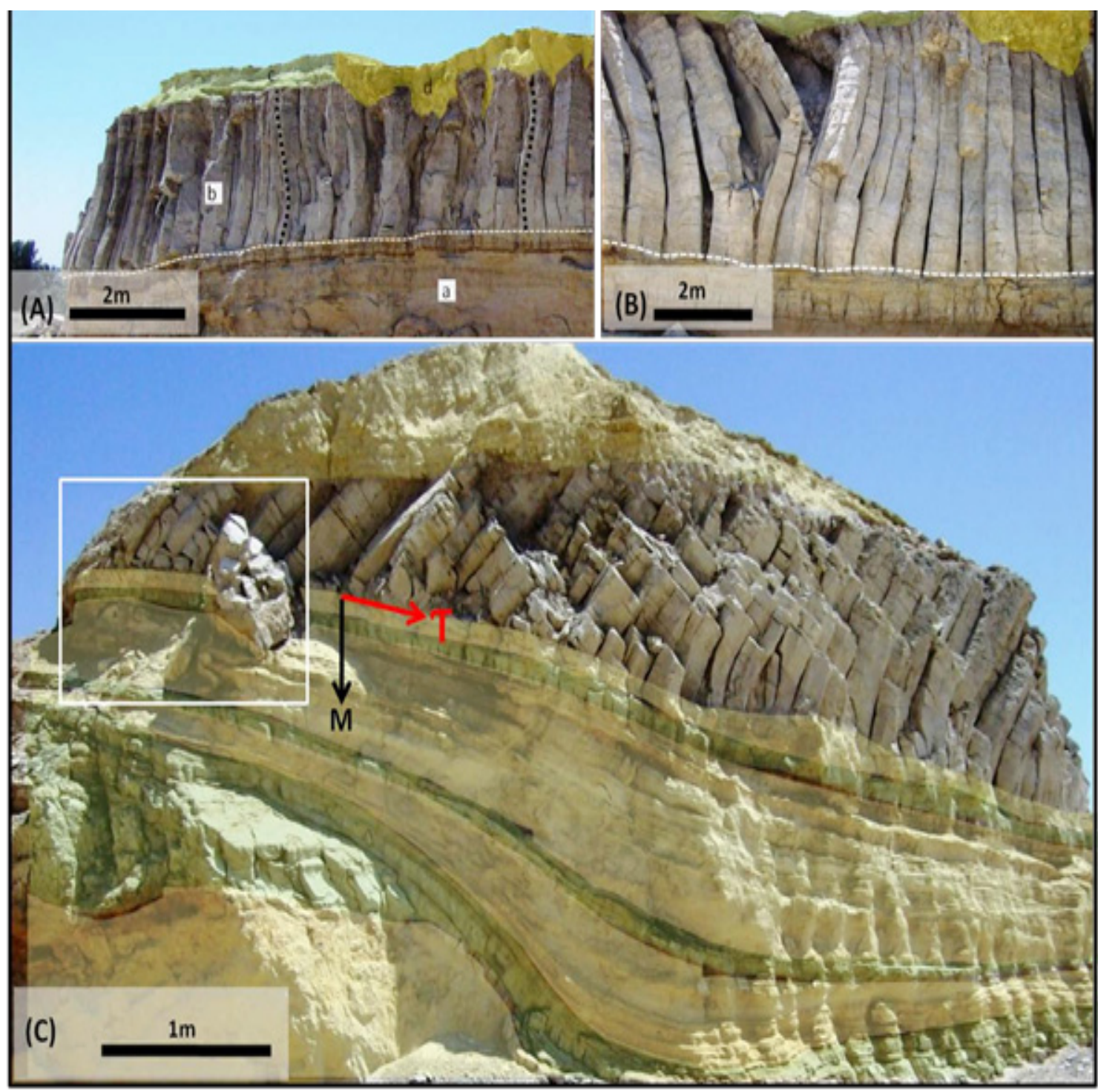

Fig. 8. (A) Vertical and twisted colonnades (b) with lower (a) and upper (c) sharp boundaries. Later submarine channeling (d) scoured into the upper colonnades depositing sand within the open spaces between fractures. (B) Vertical, twisted, and crumbled colonnades with original sand-cap not flowing into the empty spaces between colonnades and yellow color refer to channel scouring. (C) Delta-clinoforms formed of sand (yellow) and clay with orthogonal fractures in thin clay beds (green) and inclined colonnades in olive thick green intervals of clay. Shearing along laminae is noticed (white framed box). Shearing stress (T)

The spaces between the colonnades are empty without fill from the overlying sediments (Figs. 8A\&B), or partially injected especially from the lower and contiguous sediments (Figs. 7A, 9, and 10C). In some places, the colonnadeclay interval and the cap sediments are scoured (3-5m eroded thickness) by younger marine channels (Fig. 8A \& B) with a filling of fine laminated sands and delicate gastropod shells in between colonnades (Fig. 10A \& B). The sand filling is churned or horizontally laminated to up to $46^{\circ}$ angle of inclination (Fig. 10B). Undisturbed laminae and the presence of fragile shells with unbroken chambers indicate accumulation by settling rather than injection. Therefore, the fractures were open after the deposition of the sand-cap and before the submarine channeling. Hence, colonnades were developed in substrata conditions underlying the original sedimentary cap. Furthermore, the top of the colonnade clay carrier interval does not show an indication of aerial exposure and is therefore considered as continuously submerged since deposition. 
A 500m-long strip, saved from excavations while quarrying, further documents the formation of these fractures in the Qasr El Sagha Delta. The spot shows domes and little sags (Fig. 10 D-G). Tighter and looser arcs of domes in an inconsistent manner (Fig.10D-G), disharmonic folding, and clay flow are associated with a thickness variation of clay layers (Fig. 10D \& F). Differential fracturing of compositionally different clay sections is fashioned in layered fractures. Generally, the fractures are represented by branching-up rosettes in domes and branching-down rosettes in sags (Fig. 10D). Some of the fracture planes are arcuate in shape (Fig. 10E).

Clay domes and sags are crossed by filamentous fractures of a complex network and filled with sand. Fills are churned or laminated. Laminae are parallel to fracture walls or follow the wide fracture bottom (Fig. 8A \& 10EG). These form sedimentary dikelets crossing bedding surfaces and thin sills parallel to clay beds. Several sand-filling fractures are not connected with the roof sediments and show flowage features of injection, from the lower and adjacent sand, and water escapement.

The studied fractures are widely variable in style and frequency. The lower stratigraphic interval carries fractures restricted to thin clay beds hosted in a thick sand unit, where it was not possible to retain the depositional water for a long time before drying and shrinkage of the clays. Despite the high energy environment of the sand, the fractures orthogonal to horizontal bedding surfaces argue pore fluid pressure buildup due to shear stresses from strong wave action.

These fractures have irregularities and sinuous paths. The irregularities are attributed to both structural and compositional heterogeneity of clay beds where the deviation of fracture paths is recognized near-bed surfaces and loose sand intercalation. Heterogeneity makes a crack bend as it looks for the easiest path to propagate and the result is an irregular crack (Nag, et al., 2010). Fracture mechanics refer to the deviation path of a crack in a direction that makes local shear stress equal to zero (Cotterell and Rice, 1980), or towards the direction of maximum strain energy release (Lawn, 1993). The fracture aperture is a signature of the growth propagation hierarchy (Bohn,et al., 2005A \& B and Mal,et al., 2005), and consequently, the increasing fracture apertures in the middle of the claystone bed $(2 \mathrm{~mm}-0.5 \mathrm{~cm})$, relative to the thin width (1-2mm) toward the upper and lower surfaces (Fig. 3D) is attributed to earlier forms of cracks in clay and then propagated towards the upper and lower clay' surfaces. Other cases of open fracture apertures $(2-5 \mathrm{~mm})$ near the clay/sand contact and thin $(1 \mathrm{~mm})$ inside the clay (white box in Fig. 3B) indicate earlier fracture development from the clay boundaries. Thin fracture width in the sand intercalations $(<1 \mathrm{~mm})$ is attributed to different mechanical responses and the granular sliding on loose sand.

The middle clay interval hosts arcuate fractures in vertical sections of clay intercalated with silt and loose sand bands. Fractures are associated with minor (cm-scale) shear displacements normal to the crack edge (Fig. 5A-D).

Several vertical profiles of the middle clay interval show en-passant fractures. Fracture apertures in clay were found increasing or decreasing toward the top and bottom sand and silt. Wide crack apertures in clay intervals and tapering of curved crack tips toward the boundary with silt and loose fine sand (Fig. 11) indicate the initiation of cracks in clays and propagation toward the contact with the intercalated silt and sand. The stress field is perturbed around fractures in general and in the tip zone. Thus, when the elastic strain fields around two fractures overlap, the local stress fields around each fracture will interfere and curved fractures are developed (Fig. 5AD; Olsen and Pollard, 1989; and Cruikshank et al., 1991). The younger growing fracture deviates toward an already existing one and the simultaneously growing fracture tips mutually affect each other; and the degree of curvature depends on the general state of stress (Olsen and Pollard, 1989).

The approaching fracture tips entrap lenticular blocks in-between before their merging in a zigzag pattern of rough surfaces (Fig. 11B). Fractures are found merged at the boundary between heterogeneous lithology and layers of silt and sand intercalations (Fig. 11D). Advancing of the fracture process led to wide fracture aperture and smoothing of their surfaces, and the early found lenticular blocks become rock remnants associated with the fracture bands (Fig. 11D). 

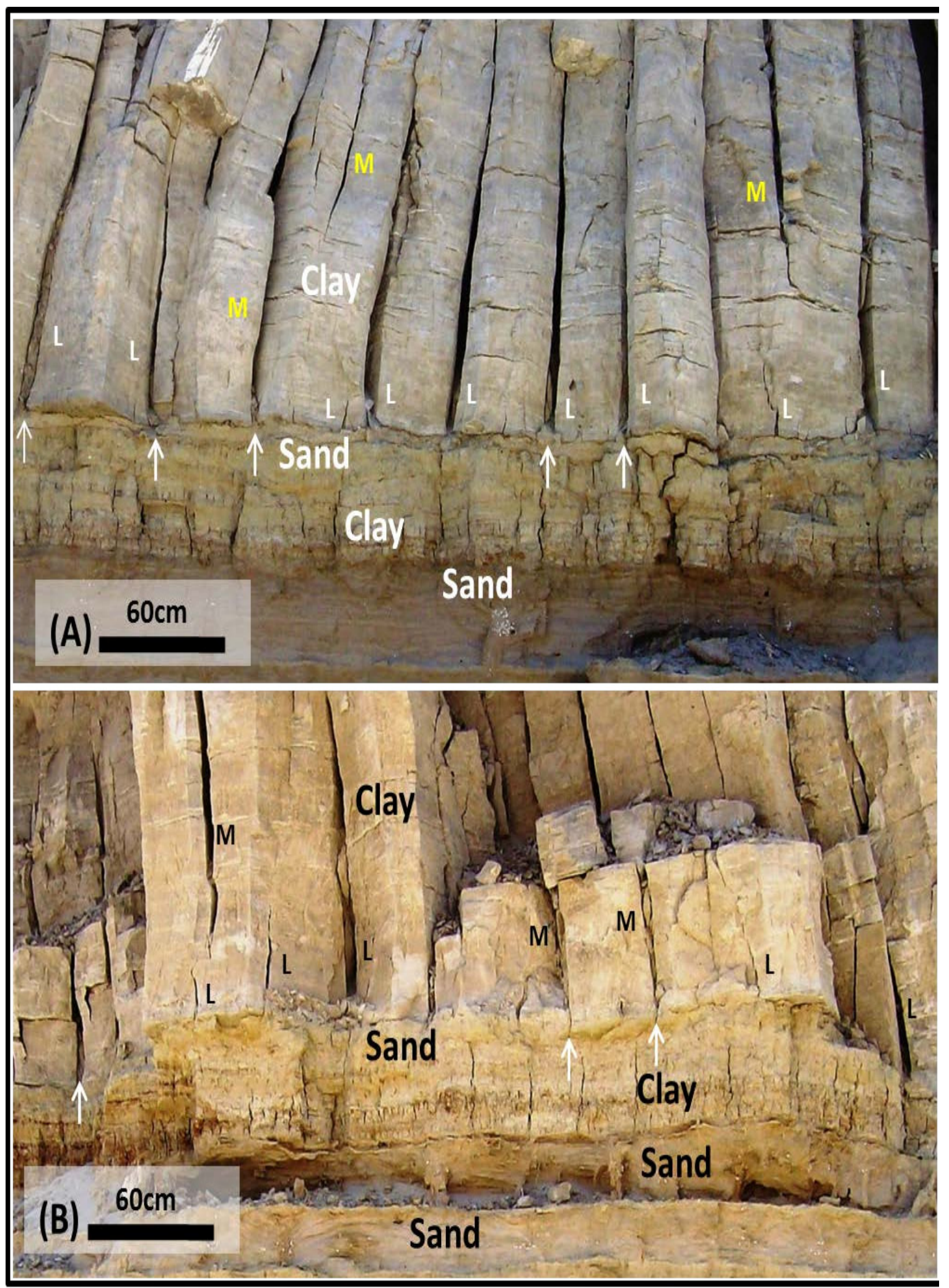

Fig. 9. Colonnades in the upper stratigraphic level are not connected with the lower fractures through a thin sand bed in between the argillaceous beds. The latter fractures taper in the upward direction and are partially injected by sand. An aperture of colonnades is wide in the lower part (referred to by letter $L$ ) and middle part (referred to by letter M). Several colonnades are injected from the lower sand (arrows). 


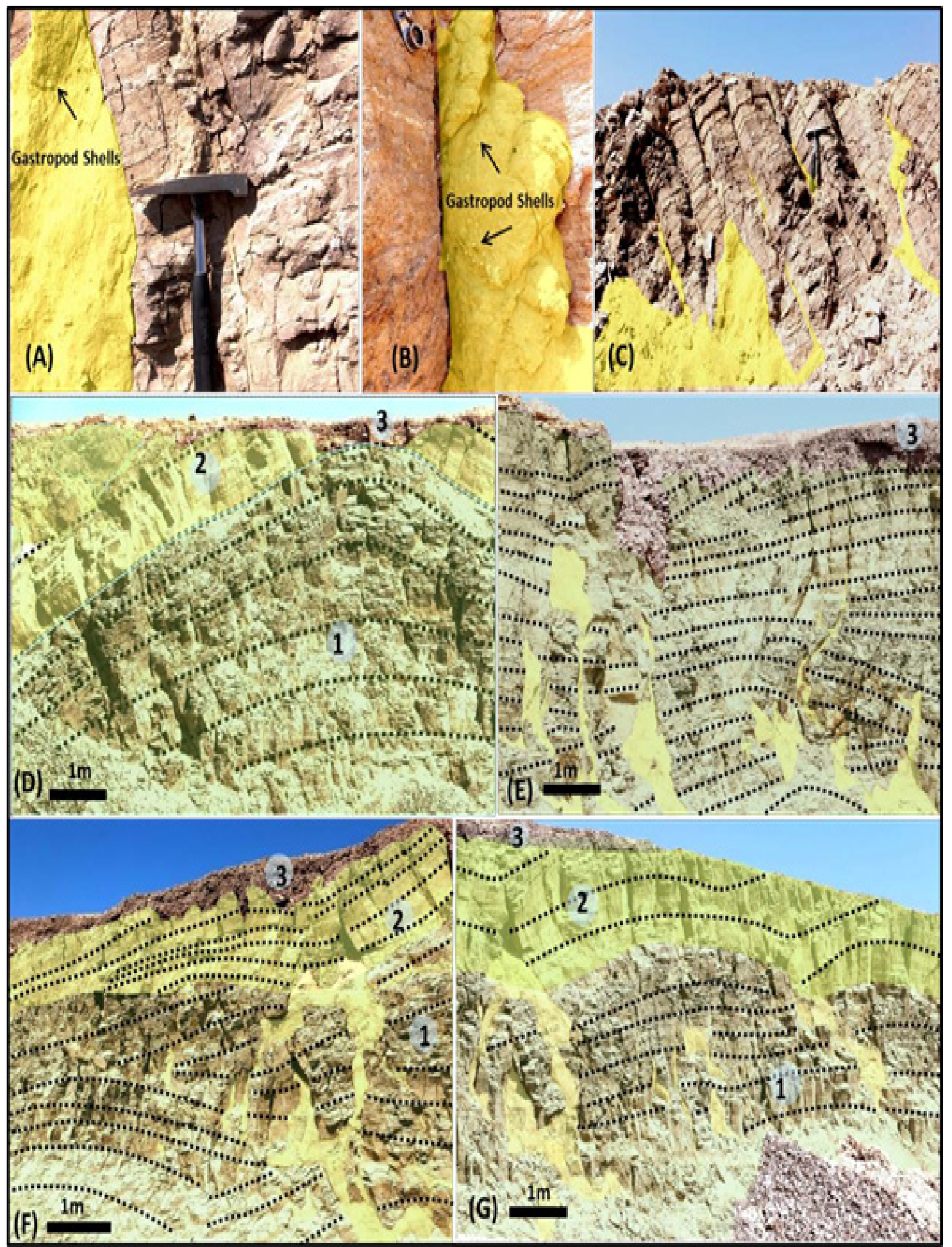

Fig. 10. (A \& B) Sand filling fractures with gastropod shells. (C) Sand injected colonnades. (D) Clay dome with gentle core and tight arcs. (E) Clay mobility with the disharmony of layer geometry, inconsistent doming with a tight core, and twisted fractures. (F) Disharmonic clay flow, arching, and sagging. (G) Two arches with a nearly flat core. In "D-G", no.1 refers to montmorillonite-rich intervals, no.2 is kaolinite-rich, no.3 is weathering rubble, the yellow color highlighting sand injections, and laminae are traced by dotted lines. 


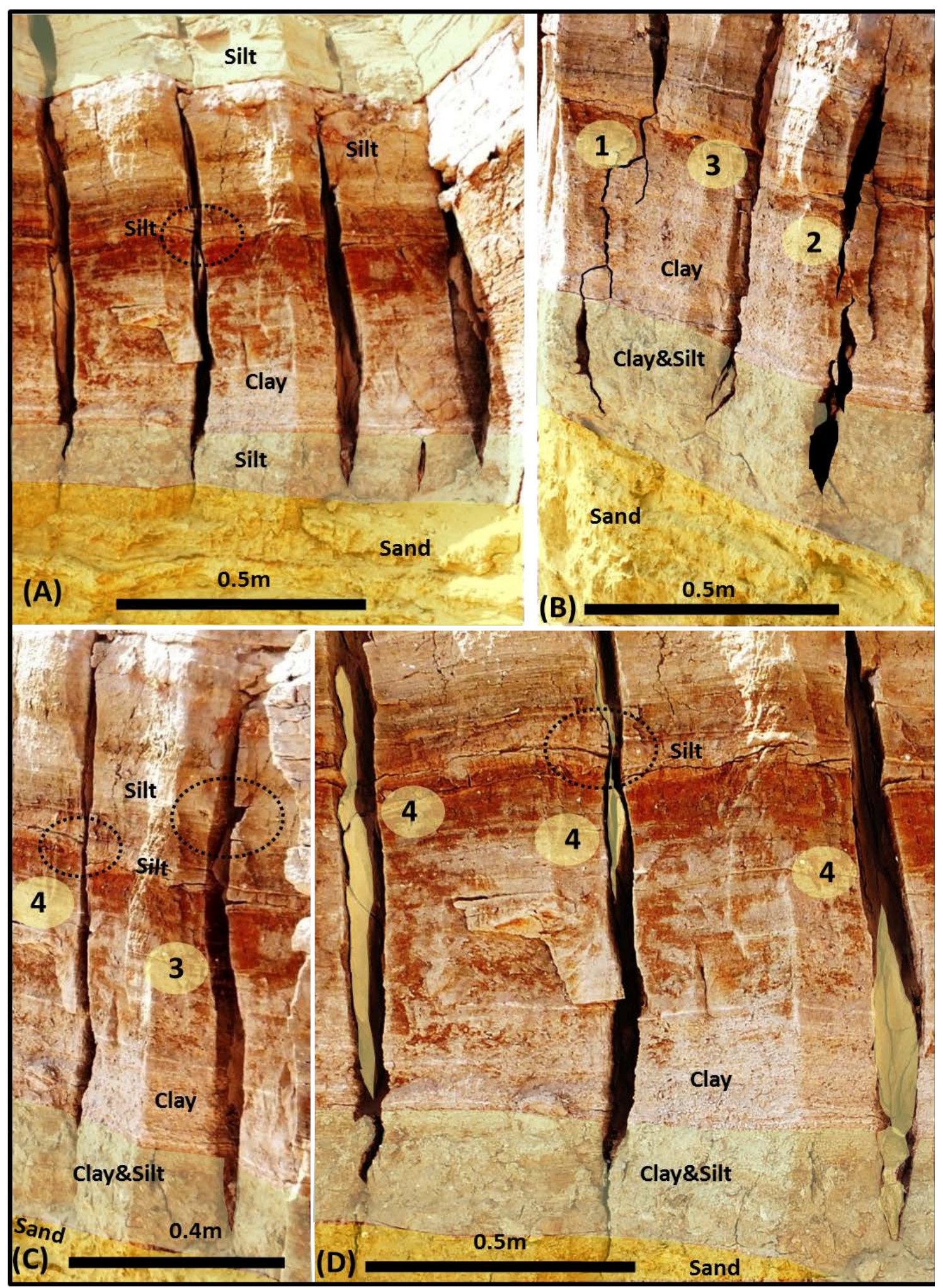

Fig. 11. (A) Elliptical fracture forms with upward and downward tapered tips. Fracture apertures are maximized in clay, while fractures did not propagate in the underlying lower coarse sand. (B) Right stepping sigmoidal and elliptical en-passant fractures. (C) Linkage of different fracture segments with remnants of jogs. (D) Fracture smoothing, further opening of apertures with rock swathes (yellow) inside the fractures. Stippled circles and ellipses refer to some zones of fracture linkages. 
The upper clay interval shows welldeveloped colonnades with high frequency and geometrical uniformity in montmorillonite-rich clay. Colonnades are often of vertical to arcuate surfaces. The counter inclination of colonnades overlying forests of delta-clinoforms (Fig. 8C) may be associated with shearing along a clay/sand lower tilted contact under the effect of clay and overburden weight. The hosted colonnades are wide in both diameter and fracture aperture (Fig. $6)$. The widths of cracks increase with their increasing age (Goehring, et al., 2015).

In vertical sections, the apertures of columnar fractures in the upper interval both increase and decrease in the middle of the colonnades and widen and taper towards both ends in the upper and lower levels (Fig. 9). Therefore, the polygonal fractures show initiation and propagation inside the clay and from the top and bottom of clay beds. Some colonnades are injected by sand from the lower and adjacent sands (Figs. 7A, 9, and $10 \mathrm{C})$ in an indication of seismicity.

The fracture surfaces are generally rough and curved and occasionally form rosettes associated with domes and sags in a good indication of ductile fracturing. The field setting refers to the continuous submergence of the upper clay section during sedimentation and cracks formation in substratal conditions.

Discussion and possible mechanism of the colonnade fractures

The formation of the colonnades during the Late Eocene time and the presence of fractures at tens of kilometers distances from the Oligocene volcanics clue out their relation to the thermally altered clastics. The dominance of course clastics in the Qasr El Sagha Formation and surface to a 50$60 \mathrm{~cm}$ burial of argillaceous beds during columnar fracturing discard their formation during basin subsidence and compaction. Some works refer to the compaction of colloids (Cartwright and Dewhurst, 1998), and infer dewatering and escape of pressurized fluids during the compaction (Gay et.al, 2004, and Tewksbury et al, 2014). Whilst the burial causes loss of the capillary water and volumetric contraction of the sedimentary particles, the sedimentary compaction should increase along the vertical axis of burial. This is making some constraints on the uniformity of the columnar fractures while burial. The field setting of the middle and upper strata-bound fracture intervals documents several remarks including: -

1- Fractures are either restricted to clay

Egypt. J. Geo. Vol. 65, (2021) intervals or tapered in the upper and lower silt and fine sand.

2- Fractures concentrate and bear regularity in montmorillonite-rich beds.

3- Colonnades are either injected by sand from the bottom or have sharp contact with the underlying sand.

4- Presence of ductile domes and sags with material flow.

5- Despite the extensive fracturing, the fracture surfaces are free of the structural features indicating solid rock extensional fracturing like plumose and hackles.

6- Presence of different fracture sets including ductile fracturing features.

7- Presence of fractures in non-evaporitic sedimentary facies.

These features may be attributed to a fracturing of a clay colloid through dewatering and shrinkage. Although clay was embedded in loose permeable sand, where water escapement was possible at the clay boundaries, many fractures were initiated inside the argillaceous beds and propagated toward upper and lower surfaces. Furthermore, the uncompacted clay and underlying sand and passive arrangement of clay laminae dismiss possible cracking by dewatering caused by rapid deposition (e.g., Plummer and Gostin, 1981; and Kidder, 1990). On the other hand, colonnades bear additional features including:

1) Shearing parallel clay-laminae is observed affecting some colonnades.

2) S o me fractures in themiddlestratigraphic interval are changed to microfaults with minor vertical displacements (mm- few $\mathrm{cm}$ ) upon cutting the upper and lower silt and sand thin beds.

3) Presence of filamentous sand injection in a complex fracture network. Sand shoots demonstrate seismicity and rapid water escapement.

4) Fractures are initiated within the clay or near the contact surfaces with upper and lower sand and silt.

5) Fractures were developed in substratal conditions with shallow (few m- thick) burial depths.

Despite the shearing associated with loading on the inclined surfaces of delta- clinoforms (Fig. $8 \mathrm{C}$ ), the other features indicate seismicity while fracturing. Pratt (1998) proposed a model of shrinkage crack formation by earthquake-induced 
shaking of interlayered mud and sand or silt under shallow burial. This model shows the initiation and widening of cracks near the interface with interlayered sand. Although this observation matches several fractures, many other fractures are devoid of this feature and show an aperture increase inside the clay beds (Fig. 12). The latter case indicates fracture initiation within the clay bed and then propagation toward interfaces with sand and silt. This can be attributed to a deviation of seismic-induced energy from the weak layer boundaries and loose sand particles to be concentrated within the clay.

Lamination in clay and its undisturbed nature may reflect slow and passive settling in a colloid before their exposure to external seismicity. Early flocculation of clays was going slow with the possible start of many cracks near clay boundaries with silt and sand. Fast dewatering, contraction, and fracture development occurred during seismicity. Several phases of dewatering and fracture development phases would be concomitant with the changeable magnitude of episodic seismicity (Fig. 12). Transmission of seismic energy from the source would be associated with changing intensity and frequency of fractures. Hence, the fracture networks injected by sand were supposedly closer to the source of seismicity.
Restriction of fracturing to fine-grained sediments, some occurrences of undisturbed contacts of colonnades either with top or bottom sediments, and absence of structures traversing the studied stratigraphic intervals rule out the possible effect of strong tectonics. Seismicity was possibly mild during the Qasr El Sagha Delta progradation and associated synsedimentary faulting and slumping. Although faults tend to act with steady slip during delta loading and slumping like creep of soft material flow, shallow and mild seismicity occurred. Subsequently, the area emerged since the Oligocene time (Dolson et al., 2014), with some deposition of continental channel sand to the north of the study area.

The intersection of open fracture sets with clay beds and laminae would enhance communication and although measurements are required, this could enhance the permeability of fracture-bearing clays. Clay fracturing during delta-buildup seismicity would be the first step in better understanding the non-conventional reservoirs in the Nile Delta, providing that the Nile Delta had undergone the same conditions. Relevant subsurface data are required for further evaluation.
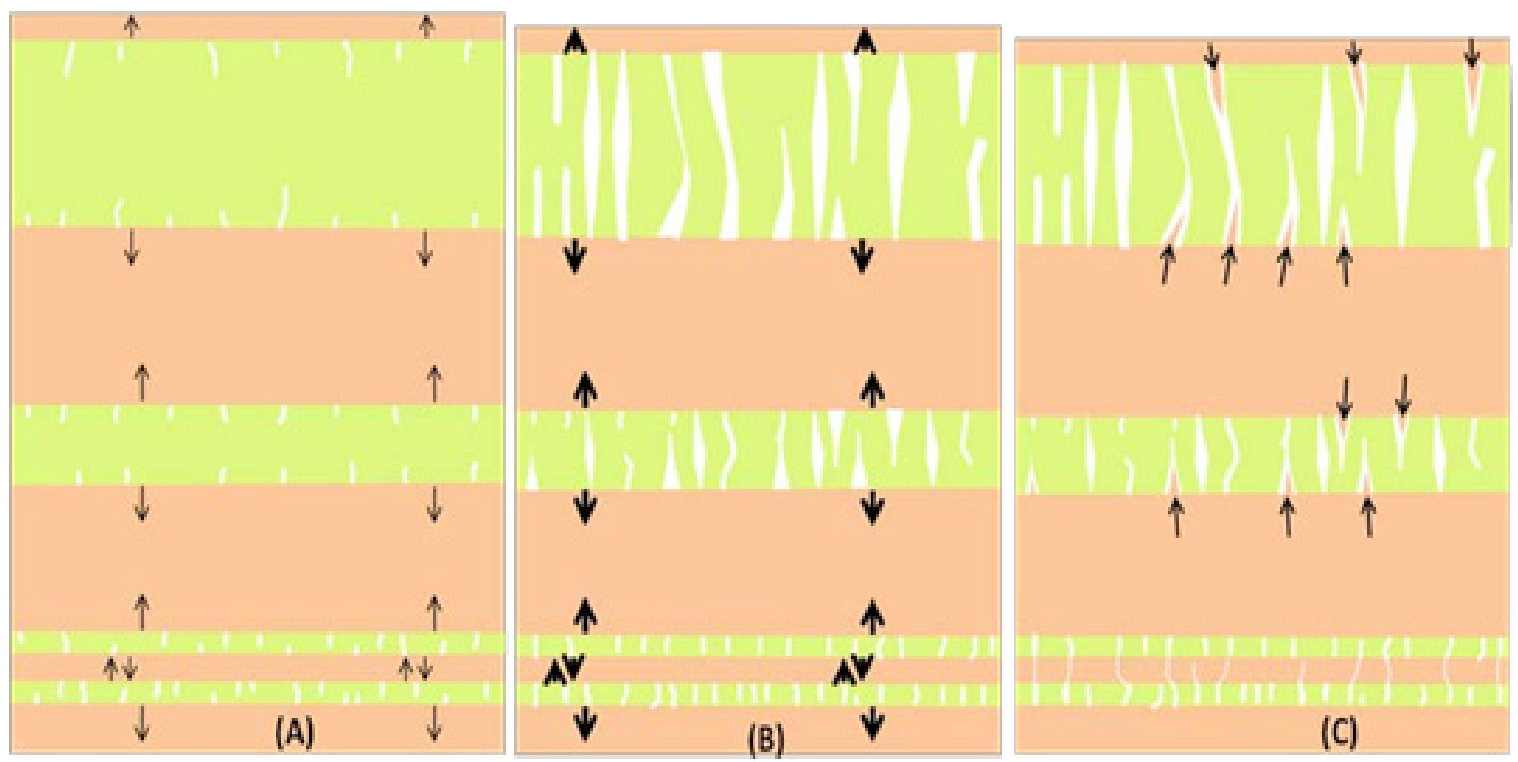

Fig. 12. Schematic model of shrinkage crack formation by repeated and mild seismicity of interlayered argillaceous beds (green) with sand and silt (orange). (A) The initial phase of mud dewatering (arrows) and $t h$ e initial formation of cracks. (B) Manifestation of dewatering and crack propagation, linking and widening associated with further seismicity. (C) Immediate sand injection in opened cracks (arrows) and little clay contraction. 


\section{Conclusions}

The Late Eocene Qasr El Sagha Delta in Fayum, Egypt hosts several clay intervals with spectacular ca $2 \mathrm{~m}$ colonnade fractures. Large diameters (up to $75 \mathrm{~cm}$ ) and fracture apertures (up to $20 \mathrm{~cm}$ ) are present in thick clay intervals. Thin clay in hosting silt and sand section is mainly dominated by tetragonal fracture patterns while hexagonal forms characterize thick clays. Fractures are mainly developed orthogonal to the clay layer interfaces and record different attitudes relative to the location in the sedimentary features associated with the propagation of the Qasr El Sagha Delta. Extensive and well-shaped fractures are concentrated in montmorilloniterich clay where pillars span the entire thickness of the clay, while kaolinite-rich and illite show fewer fractures of chaotic entablature pattern. Variations in the mineral composition of clay layers caused heterogeneity in fracture distribution and arrangements in the faces of clay quarries.

Compositional and structural heterogeneity has influenced fracture paths where wavy, arcuate, and en-passant fractures are developed. Approaching, linking, and fractures coalescing in advanced fracture propagation phases produce irregular paths and form fracture bands. Large fractures show wide apertures in the middle of clay or near interfaces with silt and sandstone. These show development of fractures in both ways from inside and from outer surfaces of clay beds. Closing some fractures towards better permeable upper and lower silt and sand layers indicates a limitation of fluid flows during fracturing. Field evidence and sedimentation continuity support fracture development on substratal conditions beneath few meters of sediment burials.

Shrinkage cracking would reflect both the rheology of the fracture-bearing sediments and the tectonic regime of the host basin. Fractures were developed by episodic pulses of mild seismicity. Fracture rosettes and associated ductile features of domes and sags and their injection by sand indicate seismicity which possibly was associated with delta-loading and syndepositional faulting. Clay fracturing during the buildup of the Late Eocene Qasr El Sagha Delta would be a step in further evaluation of subsurface data sets in the Nile Delta and the potentiality of non-conventional reservoirs.

\section{Acknowledgments}

The author expresses his gratitude to Prof. J.P. Burg from the Geological Institute, ETHZurich, Switzerland, for critical reading of the manuscript, and the laboratory facilities. The author wishes to thank Prof. El Anbaawy at Cairo University, Geology Department for fruitful discussion and X-Ray identification.

\section{References}

Abdel-Fattah, Z.A., Gingras, M.K, Caldwell, M.W. and Pemberton, S.G. (2010) Sedimentary environments and depositional characteristics of the Middle to Upper Eocene whale-bearing succession in the Fayum Depression, Egypt, Sedimentology, 57: 446476.

Allen, J. (1987) Desiccation of mud in the temperate intertidal zone: studies from the Severn Estuary and Eastern England, Philos. Trans. R. Soc. London, Ser. B, 315: 127-156.

Andrews, C.W. (1901) Preliminary note on some recently discovered extinct vertebrates from Egypt (part I), Geological Magazine Decade IV, 8: 400409.

Beadnell, H.J.L. (1905) The Topography and Geology of the Fayum Province of Egypt, Egyptian Survey Department, Cairo, 101p.

Bohn, S., Pauchard, L. and Couder, Y. (2005A) Hierarchical crack pattern as formed by successive domain divisions. I. Temporal and geometrical hierarchy, Phys. Rev. E., 71, 046214.

Bohn, S., Platkiewicz, J., Andreotti, B., Addabedia, M. and Couder, Y. (2005B) Hierarchical crack pattern as formed by successive domain divisions. II. From disordered to deterministic behavior, Phys. Rev. E, 71, 046215.

Bosworth W, Stockli D.F and Helgeson D.E. (2015) Integrated outcrop, 3D seismic, and geochronologic interpretation of Red Sea dike-related deformation in the Western Desert, Egypt-the role of the $23 \mathrm{Ma}$ Cairo “mini-plume”. J Afr Earth Sci., 109: 107-119

Brinker, C.J. and Scherer, G.W. (1990) Sol-gel science. New York, Academic Press, 908p.

Cartwright, J. and Dewhurst, D. (1998) Layer-bound compaction faults in fine-grained sediments, Geological Society of America Bulletin, 110: 12421257.

Cotterell, B. and Rice, J.R. (1980) Slightly curved or kinked cracks. Int. J. Fract., 16: 155-69. 
Cruikshank, K.M., Zhao, G. and Johnson, A. (1991) Duplex structures connecting fault segments in Entrada Sandstone, Journal of Structural Geology, 13: $185-196$.

Dolson, J.C., Atta M., Blanchard, D., Sehim, A, Villinski, J., Loutit, T. and Romine, K. (2014) Egypt's future petroleum resources: A revised look into the 21 st century, in L. Marlow, C. Kendall and L. Yose, eds., Petroleum systems of the Tethyan region, AAPG Memoir, 106: 143-78.

Gay, A., Lopez, M., Cochonat, P. and Sermondadaz, G. (2004) Polygonal faults-furrows system related to early stages of compaction-Upper Miocene to Recent sediments of the Lower Congo Basin: Basin Research, 16: 101-116, doi: 10.1111/j.13652117.2003.00224.x.

Gingerich, P.D. (1992) Marine mammals (Cetacea and Sirenia) from the Eocene of Gebel Mokattam and Fayum, Egypt; stratigraphy, age, and paleoenvironments, Univ. Mich. Pap. Paleontol., 30: $1-84$.

Goehring, L., Nakahara, A., Dutta, T., Kitsunezaki, S. and Tarafdar, S. (2015) Desiccation cracks and their patterns, formation, and modeling in science and nature. Statistical Physics of Fracture and Breakdown Series Editor Bikas Chakrabarti, Wiley-VCH Verlag GmbH \& Co. KGaA, Boschstr. 12, 69469 Weinheim, Germany. 370p.

Grapes, R. (2006) Pyrometamorphism, SpringerVerlag, Berlin, Heidelberg. 281p.

Holroyd, P., Simons, E., Thomas, M., Bown, T., Polly., P and Kraus, M. (1996) New records of terrestrial mammals from the Upper Eocene Qasr El Sagha Formation, Fayum Depression, Egypt, Palaeovertebrata, Montpellier, v. jubil. D.E. Russeu (M. Godinot \& P.D. Gingerich Eds.), 25, (2-4): 175-192.

Hughes, N. and Hesselbo, S. (1997) Stratigraphy and sedimentology of the St. Lawrence Formation, Upper Cambrian of the northern Mississippi Valley. Milwaukee Public Museum Contrib. Biol. Geol. P. 91, 50.

Khalaf, E.A., and Hammed, M.S. (2016) Morphology and development of pahoehoe flow-lobe tumuli and associated features from a monogenetic basaltic volcanic field, Bahariya depression, Western Desert, Egypt, J Afri Earth Sci., 113:165-180

Kidder, D.L. (1990) Facies-controlled shrinkage-crack assemblages in Middle Proterozoic mudstones from
Montana, USA, Sedimentology, 37: 943-951.

Kusky, T.M., Yahia, M.A. and Ramadan, T. (2001) Notes on the Structural and Neotectonic Evolution of El-Faiyum Depression, Egypt: Relationships to Earthquake Hazards, Egyptian Journal of Remote Sensing and Space Sciences, 2: 1-12.

Lawn, B.R. (1993) Fracture of Brittle Solids, $2^{\text {nd }}$ ed., Cambridge University Press, Cambridge.

Mal, D., Sinha, S., Mitra, S. and Tarafdar, S., (2005) Formation of crack networks in drying laponite films, Physica A, 346: 110-115.

Mallet, R. (1875) Origin and mechanism of production of prismatic (or columnar) structure in basalt: Phil. Mag. 4: 122-135 and 201-226.

Nag, S., Sinha, S., Sadhukhan, S., Dutta, T. and Tarafdar, S, (2010) Crack patterns in desiccating clay-polymer mixtures with varying composition, J. Phys. Condens. Matter, 22, 8p.

Olsen, J. and Pollard, D.D. (1989) Inferring paleostresses from natural fracture patterns: a new method. Geology, 17: 345-348.

Plummer, R.S. and Gostin, V.A. (1981) Shrinkage cracks: desiccation or syneresis, Jour. Sed. Petrol., 51: $1147-156$.

Pratt, B.R. (1998) Syneresis cracks: subaqueous shrinkage in argillaceous sediments caused by earthquake-induced dewatering, Sed. Geol., 17: $1-10$.

Said, R. (1962) The Geology of Egypt. Elsevier, Amsterdam, 377p.

Salem, R. (1976) Evolution of Eocene-Miocene sedimentation patterns in parts of northern Egypt, AAPG Bull., 60: 34-64.

Scherer, G.W. (1986) Drying gels: I. General theory, Journal of Non-Crystalline Solids, 87: 199-225.

Shallaly, N.A., Beier, C., Haase, K.M. and Hammed, M.S. (2013) Petrology and geochemistry of the Tertiary Suez rift volcanism, Sinai, Egypt, $J$. Volcanol. Geothermal Res., 267: 119-137.

Summer, N.S. and Ayalon, A. (1995) Dike intrusion into unconsolidated sandstones and the development of quartzite contact zones, J. Struct. Geol., 17: $997-$ 1010 .

Tewksbury, B.J., Hogan, J.P., Kattenhorn, S.A., Mehrtens, C.H.J. and Tarabees, E.A. (2014) Polygonal faults in chalk: Insights from extensive 
exposures of the Khoman Formation, Western Desert, Egypt, Geology, 42, (6): 479-482, doi: 10.1130/G35362.1.

White, W.A. (1961) Colloidal phenomena in sedimentation of argillaceous rocks, Journal of Sedimentary Petrology, 31: 560-70.

Wilde, V. (1990) Rilßstrukturen in Ablagerungen der Wealden-Fazies (Unterkreide, Berrias) im Bereich der Rehburger Berge (Niedersachsen, NWDeutschland). Neues Jahrb. Geol. Paläontol. Abh., 181: 225-239.

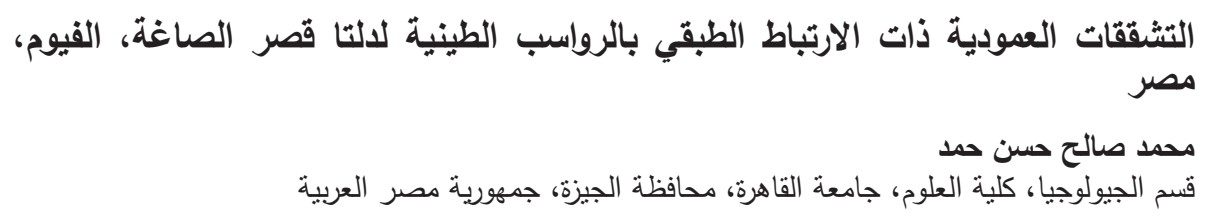

يسجل هذا العمل تشققات عمودية (colonnade fractures) متميزة وفريدة من نوعها ذات ارتباط طبقي

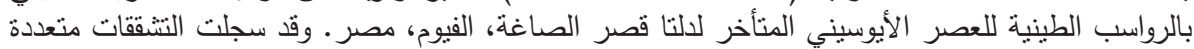

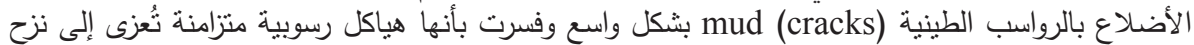

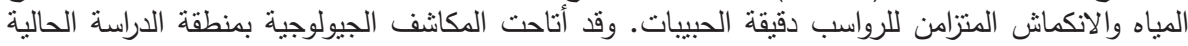

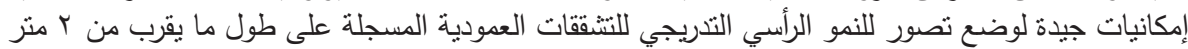

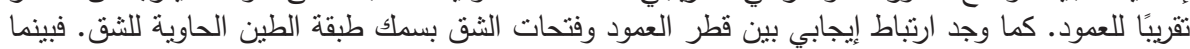

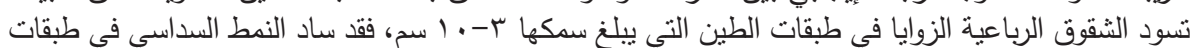

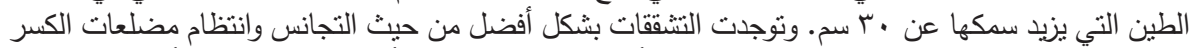

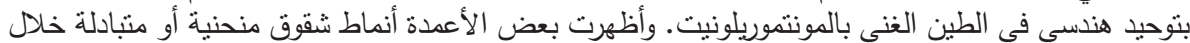

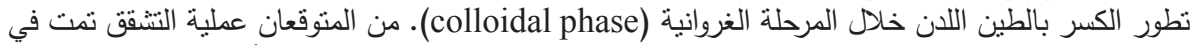

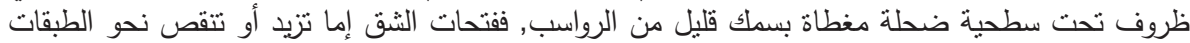

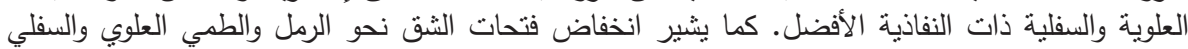

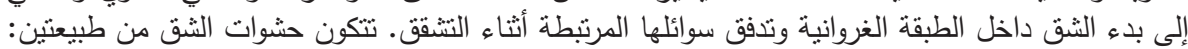

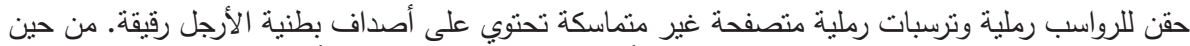

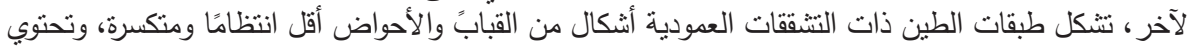

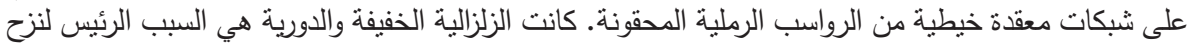

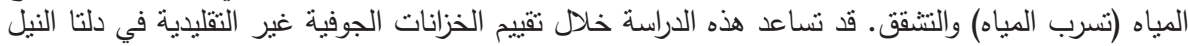
والتي خضعت لنفس الظروف الجيون ولنوبية.

Egypt. J. Geo. Vol. 65, (2021) 